\title{
INFLECTIONAL ANALYSIS OF MORPHOLOGICAL PROCESS IN TEACHING MORPHOSYNTAX THROUGH ONLINE LEARNING
}

\author{
Efransyah $^{1}$, Helsa Feby Kurnia ${ }^{2}$, Nalistya Zoheska Ildafiar ${ }^{3}$ \\ 1,2,3 IKIP Siliwangi \\ ${ }^{1}$ efransbae@gmail.com, ${ }^{2}$ helsafeby766@gmail.com, ${ }^{3}$ nalistyaz@gmail.com
}

\begin{abstract}
Inflectional is the smallest part of morphosyntax but it becomes important because it is the basic knowledge that students have to comprehend in learning and producing correct sentence. To understand them, the students have to learn it through virtual learning in COVID-19 pandemic era which has changed the way of teaching and learning process especially in Morphosyntax. This research aimed to explore the types and the students' difficulties in understanding inflectional process of morphology. This research used descriptive qualitative method to describe and to analyze the data. To collect the data, the researchers used two kinds of instruments namely pre-test, post-test, and interview. The population in this research consist of two classes from English Education Study Program at the fifth semester at IKIP Siliwangi.The result showed that the student mostly found the types of inflectional process namely plural form, 3rd singular person, past tense, progressive, comparative and superlative correctly while participle both in present and past tense form are mostly found incorrectly for they are having the higher function which are having similarity as verb progressive and as adjective at the same time. To understand the difference of the both function, the students are demanded to recognize well the structure of both.
\end{abstract}

Keywords: Inflectional Process, Morphosyntax, Online Learning

\section{INTRODUCTION}

There are four language skills, the skills are listening, speaking, reading and writing. From the four skills, writing is the most difficult one that students should be mastered, especially in learning English. As a foreign language, English has some different rules compare to other languages, especially Indonesian . One of the rules is to undertand and to comphrehend the derivational and inflectional in morphological process . Derivational is a process of morphology that changes the word class and the meaning, meanwhile Inflectional is a morphological process that maintains the word calass and rhe meaning (Martin \& Andrea, 2010:18).

Inflectional process consist of eight types namely $3^{\text {rd }}$ singular person , past Tense, progressive, past participle, plural, possessive, comparative and superlative (Katamba 1993:49) as cited in Efransyah (2020 : 39). The understanding inflectional of morphology in creating senteces correctly is very important for student of English Education Program which most of them are future teacher. It means they must have writing ability to produce sentences correctly. In the end of the study, students have to make the research paper as the requirements to get bachelor degree .

In the process of making paper, some students are still lack of understanding about some rules in constructing sentences properly, especially in morphological rules, among the material about tenses, adjective , and plural . In fact, mostly the students still get the difficulties in analyzing inflectional and derivational both from the type and the function. In this case, students are 
demmanded to comphrehend the differences and the similarities of inflectional process of morphology. Based on the background above mention, the aims of this research are to analyze the types of inflections that mostly found by the students correctly and to analyze the students difficulties in in understanding inflectional process of morphology .

According to Katamba (1993), the smallest grammatical unit in a language with complete meaning is called a morpheme. In line with this, Andrew and McCarthy (2002: 18 states that morphemes that can stand on their own are called free and bound. Bound morphemes are also called affixes, which can be divided into prefix, infix and suffix. English has only two bound morphemes, namely prefix and suffix. There is no English infix. Bound morphemes are divided into two categories, namely derivative morphemes and inflection morphemes.

Moreover, focus on inflectional affixes. An affix is a morpheme, which can be added to the base or root to form a new word. Inflectional affixes is very affected in making grammatically correct sentences, but they add some meaning to the words. They never change the parts of speech or word classes grammatically, but each grammatical category has its own set of special set of inflectional affixes.

According to the English Morphology of Lieber Rochelle (2009), there are 8 types of inflectional affixes:

1. The third-person singular form $\{-s\}$,

2. Past tense mark $\{$-ed $\}$,

3. Continuous mark $\{$-ing $\}$,

4. Past particles $\{-$ en $\}$,

5. Plural mark $\{-\mathrm{s}\}$,

6. Possessive mark $\{-$ 's $\}$,

7. The comparative suffix $\{-\mathrm{er}\}$

8. The superlative suffix $\{$-est $\}$.

According to Andrew and McCarthy (2002: 18), the types and examples of inflectional affixes based on word category categories are as follows:

Nouns : rabbit, rabbits

Verbs : : study, studied, studied

Adjectives : tall, taller, tallest

Adverbs : : soon, sooner, soonest

Possessive : mother's bag

According to Ghirardini (2011) "Online learning gives the effective method of learning; practicing as the feedback of collaboration between teaching and learning activities with individually study. The students have a chance to understand the lesson by themselves, they do not depend on the instruction and explanation from the lecturers". Moreover, Ghirardini (2011) states that "Online learning approach is able to combine the kind of online components; online contents, interactive e-lesson, electronic simulation, job aids. Online contents is a simple source to learn, it is non-interactive source such as document, PowerPoint, video or audio. These sources are non-interactive, it means that the students only reading or watching the contents without doing anything. Even though these sources are non-interactive but it can be effective if the lecturers adapt the source to reach the goal of teaching and learning process. 


\section{METHOD}

The participants of the research are the fifth semester students of IKIP Siliwangi in English Education Program and some students take more part in this research. They are students from A3 and A4 to answer the question and to find out the result under the study of this research. The researchers used two kinds of instruments in collecting the data , there are: pre-test (before teaching presentations) and post-test (after teaching presentations) to find out the information about the kind of inflections that are mostly founded by students properly and did an interview to find out the difficulties in understanding inflectional process of morphology. This research used descriptive qualitative method to describe and to analyze the result of this research by using test and interview the students .

\section{RESULTS AND DISCUSSION}

\section{Results}

The data of this research was from the students of IKIP Siliwangi at fifth semester from A3 and A4 classess in English Education Program. There are many affixes in this article so the data are taken to explore the types and the students' difficulties in understanding inflectional process of morphology .

Table 1 . Inflectional Process (Pre-Test)

\begin{tabular}{llcc}
\hline No & \multicolumn{1}{c}{ Categories } & Total & Percentage $(\%)$ \\
\hline 1. & $3^{\text {rd }}$ Singular Person & 27 & 11,02 \\
\hline 2. & Past Tense & 14 & 5.71 \\
\hline 3. & Progressive & - & - \\
\hline 4. & Past Participle & - & - \\
\hline 5. & Plural & 204 & 83,2 \\
\hline 6. & Possessive & - & - \\
\hline 7. & Comparative & - & - \\
\hline 8. & Superlative & - & - \\
\hline & Total & $\mathbf{2 4 5}$ & $\mathbf{9 9 , 3}$ \\
\hline
\end{tabular}

Table 2. Inflectional Process (Post-Test)

\begin{tabular}{llcc}
\hline No & \multicolumn{1}{c}{ Categories } & Total & Percentage $(\%)$ \\
\hline 1. & $3^{\text {rd }}$ Singular Person & 88 & 21,83 \\
\hline 2. & Past Tense & 42 & 10,42 \\
\hline 3. & Progressive & 77 & 19,10 \\
\hline 4. & Past Participle & - & - \\
\hline 5. & Plural & 114 & 28,28 \\
\hline 6. & Possessive & - & - \\
\hline 7. & Comparative & 41 & 10,17 \\
\hline 8. & Superlative & 41 & 10,17 \\
\hline & Total & $\mathbf{4 0 3}$ & $\mathbf{9 9 , 9 7}$ \\
\hline
\end{tabular}




\section{Discussion}

\section{a. Data from pre test and discussion}

From the table of pre test above, it can be seen that the students mostly found correctly of inflectional process namely plural $(83,2 \%)$, third singular person $(11,02 \%)$, and past tense $(5,71 \%)$. They could find them all correctly for they are easier to recognize. In the beginning, the most students still do not recognize the other inflectional processes such as progressive, participle, possessive, comparative and superlative. After conducting a pre test, the reserachers gave some treatments to the whole students related to inflectional process of morphology. The researchers explained the materials simply and clearly in order they are easily to be understood by the students.

\section{b. Data from post test and discussion}

After giving the treatments, form the post test table above, the researchers found that the mostly students found the inflectional process correctly such as plural $(28,28 \%)$, third singular person $(21,83 \%)$, progressive $(19,10 \%)$, past tense $(10,42 \%)$, comparative $(10,17 \%)$ and superlative $(10,17 \%)$. The researchers found that in the post test, the mostly inflectional process that found by the students correctly are the same as in the pre test which are plural form, the third singular person and past tense. But in the post test, the past tense is in the fourth position after progressive followed by comparative and superlative in the last position. Here, the researchers did not find the students who answer the participle correctly. Based on the interview, the mostly students considered participle as the most difficult part of inflectional process to be recognized for they have higher function. It means that they can functionate as progressive and as an adjective (both present and past participle).

\section{CONCLUSION}

After conducting the research, the result shows that the students mostly found the types of inflectional process namely plural for plural number of noun, the $3^{\text {rd }}$ singular person for the verbs, progressive for the verbs, past tense form for the verbs, comparative and superlative for asjectives in composing proper sentence. While in participle, the researchers found that the students still did some mistakes. It is because the using of participle in inflectional process of morphology could have multi or higher functions which are functioning as progressive and adjective.

So it made the students got difficulties to differentiate both functions. That is why, the students are demanded to comprehend about inflectional types and structure especially in participle process in composing the proper sentences .

\section{ACKNOWLEDGMENTS}

Alhamdulillah all gratitude to Allah S.W.T who has gaven his blessing to the writers, so they can finish this article well and in healthy condition. The writers would like to say the biggest thanks to IKIP Siliwangi Bandung which has given the chance to publish this article. The last but not least, the writers also say thanks to blind reviewer who reviews this article as well as to the editorial team so this article may be published perfectly. 


\section{REFERENCES}

Adhe R K (2018). Model Pembelajaran Daring Matakuliah Kajian PAUD di Jurusan PG PAUD Fakultas Ilmu Pendidikan Universitas Negeri Surabaya. JECCE-Journal of Early Childhood Care and Education. ISSN: 2615-1413

Aprianti, I. N., \& Parmawati, A. (2020). Derivational And Inflectional Morpheme Analysis On The Song Lyrics Of Lady Gaga “A Star Is Born” Album. Project (Professional Journal Of English Education), 3(3), 322-328.

Booij G (2006), Inflection and Derivation. In: Keith Brown, (Editor-in-Chief) Encyclopedia of Language \& Linguistics, Second Edition, volume 5, pp. 654-661. Oxford: Elsevier

Efransyah. (2020). Morphosyntax. Jawa Tengah : Pena Persada.

Hakim, Lukmanul (2017) An Error Analysis of Using Inflectional Affixes in Students' Writing Ability at The Third Semester of STAIN Jurai Siwo Metro in Academic Year 2016/2017. Undergraduate thesis, IAIN Metro.

Maulidina, S., Indriyani, F., \& Mardewi, T. (2019). Derivational and Inflectional Morphemes in the Jakarta Post. Journal of English Teaching and Research, 4(2), 104-122.

Ninsiana, W., \& Hakim, L. (2018). An Analysis Of Inflectional Affixes Error In Argumentative Writing. Pedagogy: Journal of English Language Teaching, 6(1), 1. https://doi.org/10.32332/pedagogy.v6i1.1116

Sukmacahyadi, D. (2018). An Analysis of Inflectional Affixes on English Department Students 'Undergraduate Thesis Abstracts, 8(5), 17-21.

The Consistency of the Use of Inflectional and Derivational Affixes for Word Formation in Students' Writing. (2017). English Education Journal, 7(3), 270-278. https://doi.org/10.15294/eej.v7i3.20746

Tri Widari, K., Udayana, I. N., \& Artawa, K. (2018). Morphosyntactic Analysis on English Inflectional Affixes with Special Reference to The Jakarta Post. Humanis, 22(1993), 751. https://doi.org/10.24843/jh.2018.v22.i03.p27 